\title{
WETENSKAPLIKE BEOEFENING VAN DIE \\ TEOLOGIE AAN DIE TEOLOGIESE SKOOL.
}

Hierdie artikel kan, weens verskillende oorsake wat hier nie genoem hoef te word nie, slegs 'n vlugtige terugblik in die verlede wees, om dan na te speur wat die moontlikhede vir die toekoms is.

Wat onder die term "wetenskaplik" verstaan moet word, is nie so maklik om te sê nie. Die opvattinge sal verskil. Argitekte hoef nie almal eenders te bou nie. Wat in die algemeen verlang word, is 'n hegte, welsluitende grondslag, 'n styl wat metodies die regte lyne volg en 'n kritiese gebruikmaking van die voorhande materiaal.

En wat die naam ,teologie" betref, dit is vir ons geen godsdienswetenskap of bestudering van een of ander empiriese verskynsel of selfs uitbouing van 'n denkbeginsel op godsdienstige gebied nie. Die teologie is vir ons die sistematisering van die geopenbaarde kennis van God soos vervat in die Heilige Skrif as principium unicum theologiae.

Die naaste doel met die stigting van die Teol. Skool was nie die wetenskaplike beoefening van die teologie as sodanig nie. In 'n onmiddellike noodtoestand moes voorsien word: daar was manne nodig om die vakante gemeentes te bedien. Daarom het prof. D. Postma al met die opleiding van dienaars volgens art. 8 K.O. op sy verre togte deur die land begin. Hierdie opleiding is toe op vaste voet bestendig deur die stigting van die Skool te Burgersdorp in 1869.

Maar dit wil nie sê dat die praktyk eksklusief die doel beheers het nie. Prof. D. Postma en prof. J. Lion Cachet, die eerste dosente, soos hulle in 
die begin genoem is, was albei manne van Europese vorming, die een meer sistematies gevorm, die ander meer geniaal aangelê. Hulle boekerye het genoegsaam getuienis afgelê dat hulle vir die studie strenge eise gestel het.

Die saak staan dan ook so dat 'n mens nouliks kan spreek van 'n beoefening van die teologie alleenlik om die teologie self of in die algemeen van die wetenskap alleenlik om die wetenskap self. Dit is 'n ware woord wat Kuyper in sy Ensyclopaedie skrywe dat die weg van die wetenskap nie deur lug en wolke gaan nie, maar langs die begane grond waar die mensekinders wandel. Die praktyk wat sy eise stel, is ók bevorderlik vir die beoefening van die wetenskap. So was dit ook met die opleiding van predikante onder ons. Meer en meer is die vereistes opgeskuiwe en die studiejare verleng, totdat dit eindelik gekom het tot 'n uitbouing van die curriculum konform die eise wat aan die Vrye Universiteit te Amsterdam gestel is, natuurlik met inagneming van ons toestande hier te lande. Selfs het dit sover gekom dat, in samewerking met die P.U.K., ons predikante in staat gestel is om te ding na die hoogste grade in die teologie.

Ons Teol. Skool het gelyke tred gehou met die algemene ontwikkeling op wetenskaplike erf in ons land. Eers kon geen universitêre grade in die teologie hier verkry word nie. Daarvoor moes die aspirante na Europa, spesiaal na Nederland, gaan. Terwyl dié toestand voortgeduur ' het, was dit saak om die eie kandidaatswerk so hoog moontlik op te skuiwe. Nadat egter in die akademiese wêreld die gewenste verandering ingetree het, het die Geref. Kerk en sy Teol. Skool deur middel van die P.U.K. dadelik die aangebode geleentheid benut om vir teoloë die weg te baan ter verwerwing van die algemeen erkende grade op teologiese terrein. Dat dit die wetenskaplike naam van die Teol. Skool ten gocde gekom het, hoef nic meer betoog te word nic.

Maar nog ' $n$ ander verskynsel uit die ou tyd wys in die goeie rigting. Deurdat prof. D. Postma twee seuns van hom na Somerset-Oos gestuur het om daar hulle akademiese grade te haal, het hy metterdaad getoon dat ' $n$ wetenskaplike opleiding deur hom van groot waarde geag is. In verband met ons onderwerp wil dit sê dat die bedoeling nie kon gewees het om wetenskaplike werk in die algemeen te bevorder terwyl die teologie aan sy lot oorgelaat word nie.

'n Bevestiging van hierdie bewering vind ons in die feit dat in die $11 \mathrm{e}$ Algem. Vergadering van die gemeentes in die Z.A.R., in samehang met die opleiding van predikante vir die Geref. Kerk, nadruklik verwys word nd wat à Brakel in sy „Redelijke Godsdienst" oor die onderwerp „Geleerdheid" ten beste gee (hoofst. 28, II(1). Daar word gehandel oor 
die propedeuse (ou tale ens.) en oor die teologie self. Voorbereidende studie, sê Brakel, is nodig om des te beter teologiese sake te behandel. „Maar 'n grondige godgeleerdheid is volstrek nodig in 'n leraar. 'n Mens moet hom nie tevrede hou met 'n kort begrip van buite te leer nie ... Tot 'n goeie teologant word vereis diepe deurdringende kennis van allerlei teologiese sake waarvan hy deur baie oefening 'n hebbelikheid verkry het." Hierdie hele paragraaf kan vandag nog met profyt deur die teoloog ragelees word.

Ons kan dus aanneem dat proff. D. Postma en J. Lion Cachet, saam net hulle medestanders, onder wie drie seuns van prof. Postma, voorbereidende werk gedoen en materiaal versamel het, sodat die Teol. Skool uiteindelik aan al die eise van 'n Hoëskool kon beantwoord.

Wat die teenswoordige betref, word voortdurend geywer on die teol. studente ten hoogste vir die toekomstige amp bekwaam te maak. Niemand sal dit ons dan ook wil ontstry nie dat die regte wetenskaplike vorming bevorderlik is vir die vrugbare ampsbediening. Daarom word die een gedoen en die ander nie nagelaat nie.

Ondanks alles wat alreeds bereik is, bly dit vir die toekoms 'n vereiste dat die professoretal aan die Teol. Skool vermeerder moet word. Die noodsaaklike werk kan wel behartig word, maar soveel meer staan op die program. 'n Aanvang is alreeds gemaak met die skrywe van kommentare op die Heilige Skrif, waartoe ook lerare van ons Kerk en professore en lerare van die Ned. Geref. Kerk sal săamwerk. Maar dié werk sal nie vlot loop as nic meer tyd bepaaldelik daarvoor afgesonder kan word nie. Die betrokke professore moet nie net tyd vind om die gelewerde werk vóór die uitgawe na te sien nie--hulle moet self ook kommentare skrywe.

Ongelukkig is daar elke dag soveel wat onmiddellik die aandag verg, dat wat enigsins kan wag, opsy geskuiwe word. En dan moet ons nog in herinnering bring dat van die teol. professore verwag word dat hulle die meerdere vergaderings sal bywoon, dat hulle hier en daar in die gemeentes sal optree, dat hulle adviese sal skrywe onr ingewikkelde kerkregtelike kwessies wat aan hulle voorgelê word; en daar is nog soveel meer. Hoe moet dan die rustige tyd gevind word vir wetenskaplike arbeid na buite?

'n Viertal teol. professore is tog wel die minimum: een vir die O.T. en aanverwante vakke, een vir die N.T. en aanverwante vakke, een vir die Dogmatiek ens. en een vir die historiese- en praktiese vakke. As dan nog, soos nou die geval is, van die kant van die P.U.K. vir die graadeksamens hulp verleen word, sal dit ons seker 'n hele ent vorentoe bring. So lank as daar maar net voortgang is. Verder wil ons hier nie vooruitlonp op voorstelle dienaangaande wat by die a.s. sinode aanhangig gelllak sal word nie. 
Nou kom ons tot die biblioteek. In hierdie opsig is aanmerklike uitbreiding absoluut noodsaaklik. Voortdurend is boeke aangekoop, maar vir die hoëre graadeksamens was dit nie altyd toereikend nie. Die student self moes dikwels die tekort aanvul. In hierdie opsig kan die Teol. Skool en P.U.K. ook saamwerk. Groter somme sal spesiaal vir die nodige uitbreiding beskikbaar gestel moet word. As die oorlog in Europa ten einde is, sal dadelik bestellinge geplaas moet word om ons agterstand in te haal en om wat nuut verskyn het, aan te koop.

Vanself sal aan die Teol. Skool die lokaliteit vir die boekery baie vergroot moet word. Op die oomblik is die biblioteek-ruimte geheelenal gevul. Selfs beskik die studente nie oor 'n aparte lees- en studiesaal nie.

Hoe sal 'n timmerman of messelaar sy werk kan doen as hy nie oor die nodige gereedskap beskik nie? Is dit nie selfs die strewe om die gereedskap nog altyd te verbeter nie? Hoe kan dan die wetenskaplike arbeid deeglik verrig word as ons op 'n behelperige manier moet voortarbei? Laat tog veral vermoënde manne en vroue wat ons goedgesind is, aan hierdie behoeftes van die Teol. Skool dink! Hier moet nog aangestip word dat so pas deur die Kuratorium van die Teol. Skool besluit is om aan teol. studente van die vierde jaar die reg te verleen om in daardie jaar ook die eerste deel van die M.Div.-eksamen af te lê, mits die studicvakke van daardie jaar ooreenkom met die kandidaatsvakke.

Hierdeur word nie alleen vir meerdere studente die pad geopen om verder in die teologie te studeer nie, maar tegelyk word aan hulle die geleentheid gebied om onder persoonlike toesig van die professor te studeer-iets waaraan meer en meer behoefte gevoel word. Ons hoop dat hierdie persoonlike samewerking die begin sal wees van wat ons graag in vooruitsig wil stel, naamlik dat kollege gegee sal word-ook met die oog op die hoëre teologiese eksamens.

Ten slotte nog dit.

Studie is 'n skone, verheffende besigheid, des te skoner en verheffender as ons altyd dieper kan indring. Maar die studie van die teologie is die skoonste en mees verheffende van almal, omdat die beginsel, bestand en einddoel van alle geskape dinge vir ons vaslê in die Woord van God. Die vrae wat ons hoof deurkruis en ons siel soms tot sterwens toe kwel, is daarin opgelos. Die misteries wat die skepping deurbewe, kom daarin tot openbaring, soos die luggolwe aftril op die drade van die opvangtoestel.

Jesaja sê dit dan ook in sy onoortroffe taal: „Dit het die Here behaag, om sy geregtigheid ontwil, om die onderwysing groot en heerlik te maak" (42:21). Die profect sing hier die lof van die ganse Godsopenbaring soos dit aan Israel toebetrou is. Daarby kom onder die nuwe 
bedeling die hele Nuwe Testament. Wat 'n onskatbare voorreg om die hele Bybel te besit en te lees! Onskatbaar insonderheid as ons dit mag bestudeer. Hier is ewigheidswerk.

Volgens ons Kerkorde is dit die amp van die doktore of professore om die Heilige Skriftuur uit te lê en die suiwere leer teen die ketterye te verdedig (art. 18). Vanself kom hier nog ander teologiese vakke by; maar alles moet tog om die Heilige Skrif gegroepeer word en moet dien om die Skrif heerlik te laat wees in ons oë.

Maar die werk van die professor is ook die werk van die student. Dit moet ook vir hom 'n lus en liefde wees om aanhoudend dieper in te dring in dic geheime skatkamers van die Woord.

Vanself spreek dit dat ek hier onder teologie verstaan die teologie volgens Gereformeerde belydenis.

Laat dan ons strewe altyd wees: Tot die Wet en tot die Geutienis!

Potchefstroom.

J. D. DU TOIT. 